\title{
Simulation of nitrogen deposition in the North China Plain by the FRAME model
}

\author{
Y. Zhang ${ }^{1}$, A. J. Dore ${ }^{2}$, X. Liu ${ }^{1}$, and F. Zhang ${ }^{1}$ \\ ${ }^{1}$ College of Resources and Environmental Sciences, China Agricultural University, Beijing 100193, China \\ ${ }^{2}$ Centre for Ecology and Hydrology, Edinburgh, Bush Estate, Penicuik, Midlothian EH26 0QB, UK
}

Received: 11 July 2011 - Published in Biogeosciences Discuss.: 11 August 2011

Revised: 27 October 2011 - Accepted: 29 October 2011 - Published: 15 November 2011

\begin{abstract}
Simulation of atmospheric nitrogen (N) deposition in the North China Plain (NCP) at high resolution, $5 \times 5 \mathrm{~km}^{2}$, was conducted for the first time by the Fine Resolution Atmospheric Multi-pollutant Exchange (FRAME) model. The total $\mathrm{N}$ deposition budget was $1481 \mathrm{Gg}$ in this region, with $77 \%$ from reduced $\mathrm{N}$ and $23 \%$ from oxidized $\mathrm{N}$, and the annual deposition rate $\left(47 \mathrm{~kg} \mathrm{Nha}^{-1}\right)$ was much higher than previously reported values for other parts of the world such as the UK $\left(13 \mathrm{~kg} \mathrm{Nha}^{-1}\right)$, Poland $\left(7.3 \mathrm{~kg} \mathrm{Nha}^{-1}\right)$ and EU27 (8.6 kg Nha $\left.{ }^{-1}\right)$. The exported $\mathrm{N}$ component $(1981 \mathrm{Gg})$ was much higher than the imported $\mathrm{N}$ component $(584 \mathrm{Gg})$, suggesting that the NCP is an important net emission source of $\mathrm{N}$ pollutants. Contributions of $\mathrm{N}$ deposition budgets from the seven provinces in this region were proportional to their area ratios. The calculated spatial distributions of $\mathrm{N}$ deposition displayed high rates of reduced $\mathrm{N}$ deposition in the south and of oxidized $\mathrm{N}$ deposition in the eastern part. The $\mathrm{N}$ deposition exceeded an upper limit of $30 \mathrm{~kg} \mathrm{Nha}^{-1}$ for natural ecosystems over more than $90 \%$ of the region, resulting in terrestrial ecosystem deterioration, impaired air quality and coastal eutrophication not only in the NCP itself but also in surrounding areas including the Bohai Sea and the Yellow Sea.
\end{abstract}

\section{Introduction}

Nitrogenous pollutant $\left(\mathrm{NH}_{3}\right.$ and $\left.\mathrm{NO}_{\mathrm{x}}\right)$ emissions have increased sharply in the last three decades in China due to the rapid development of agriculture and industry (GAINS, 2009; EDGAR, 2011; REAS, 2006). The increased reactive $\mathrm{N}$ emissions damage air quality (Fowler et al., 1998; Erisman et al., 2004) and are also deposited back to surrounding

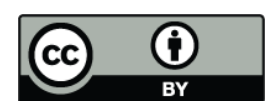

Correspondence to: X. Liu (liu310@cau.edu.cn) terrestrial and aquatic ecosystems, contributing to severe environmental problems (Castro et al., 2002; Matson et al., 2002). Atmospheric transport models (ATMs) have been developed and applied to long-range multi-pollutant transport and distribution in Europe and North America for decades, e.g. EMEP, RADM, MATCH, and ACDEP (Jonson et al., 1998; Hertel, et al., 2002; Simpson et al., 2003; Langner et al., 2005). However, application of models to calculate $\mathrm{N}$ deposition in China, especially in high $\mathrm{N}$ deposition regions, has been rare. Dentener et al. (2006) assessed the global distribution of $\mathrm{N}$ deposition by different ATMs and found that China (especially eastern China) has become one of the highest $\mathrm{N}$ deposition regions in the world.

The North China Plain (NCP) is an intensively managed agricultural region and economically developed area. The seven major provinces on the NCP, namely Beijing, Tianjing, Hebei, Shandong, Henan, Jiangsu and Anhui, share only $8 \%$ of the total area of China but contribute $37 \%$ of the total national GDP (China Statistical Yearbook, 2009). They consume $27 \%$ of the total $\mathrm{N}$ fertilizer and $26 \%$ of the total energy nationally (China Statistical Yearbook, 2009), making the NCP one of the great emitters of nitrogenous pollutants (Wang et al., 2005; Zhang et al., 2010; Richter et al., 2005; Clarisse et al., 2009) and one of the high $\mathrm{N}$ deposition areas both nationally and globally (Zhang et al., 2008; Shen et al., 2009; He et al., 2010). Although global or continental scale studies of $\mathrm{N}$ deposition cover this region (Dentener et al., 2006; Holloway et al., 2002), it is impossible to describe the situation in a region with an area of $313295 \mathrm{~km}^{2}$ at resolutions from $0.5^{\circ}$ to $10^{\circ}$. Kim et al. (2003) used a nested grid with a grid size of $8.9 \mathrm{~km}$ to model the acid deposition in the Northeast Asia, which covered parts of the NCP. Unfortunately, the simulation was conducted for the year 1996, which is difficult to apply to recent situations. Thus, it is critical to model the long-range transport and regional distribution of $\mathrm{N}$ concentration and deposition at higher resolution in this $\mathrm{N}$ deposition "hotspot".

Published by Copernicus Publications on behalf of the European Geosciences Union. 
The FRAME (Fine Resolution Atmospheric Multipollutant Exchange) model, a Lagrangian model which was originally developed in the UK, was used to simulate $\mathrm{N}$ deposition in the NCP. Simulation of the spatial distribution of $\mathrm{N}$ deposition at fine resolution, $5 \times 5 \mathrm{~km}^{2}$ grid, was undertaken for the year 2008. The import, export and transport of nitrogenous pollutants in the NCP were calculated. The results of the model form the essential inputs for estimation of exceedance of critical loads for $\mathrm{N}$ deposition and estimation of the abatement of pollutant gases required to protect natural and semi-natural ecosystems. The objectives of this study were to assess the distribution of N deposition in the NCP at $5 \mathrm{~km}$ resolution and to evaluate the environmental consequences of such $\mathrm{N}$ deposition to the NCP and surrounding regions.

\section{Methods}

\subsection{Case study region}

The domain in the study was about $10^{\circ}$ in longitude from $112^{\circ}$ to $122^{\circ} \mathrm{E}$ and $10^{\circ}$ in latitude from $31^{\circ}$ to $41^{\circ} \mathrm{N}$, comprising 11 provinces/municipalities, i.e. Beijing, Tianjin, Hebei, Henan, Shandong, Shanxi, Anhui, Jiangsu, Hubei, Liaoning, Inner Mongolia, as well as parts of the Bohai and Yellow Seas, bordering and within the model domain but may not belong to the NCP. The location, boundary and landuse of the NCP are outlined in Fig. 1, covering parts of Beijing, Tianjin, Hebei, Henan, Shandong, Anhui and Jiansu provinces (or municipalities). The total area of the NCP is $313300 \mathrm{~km}^{2}, 39 \%$ of the model domain area.

\subsection{Model application}

The FRAME model is an atmospheric transport model used for modeling the long-range transport and annual deposition of $\mathrm{NH}_{\mathrm{x}}\left(\mathrm{NH}_{3}\right.$ and $\left.\mathrm{NH}_{4}^{+}\right), \mathrm{NO}_{\mathrm{y}}$ and oxidized sulphur $\left(\mathrm{SO}_{\mathrm{x}}\right)$. It uses statistically weighted straight-line trajectories and is a multi-layer, Lagrangian model with high horizontal $\left(5 \times 5 \mathrm{~km}^{2}\right)$ and vertical (33 layers) resolution. The model is described in detail by Singles et al. (1998); Fournier et al. (2004) and Dore et al. (2007).

Spatial distributions of $\mathrm{NH}_{3}, \mathrm{NO}_{\mathrm{x}}$ and $\mathrm{SO}_{2}$ emissions at $5 \times 5 \mathrm{~km}^{2}$ input into the model are shown in Fig. 2. An NCP $\mathrm{NH}_{3}$ emission inventory and map for the year 2008 were calculated following the methodology adopted by Zhang et al. (2010) for the year 2004. The $\mathrm{NO}_{\mathrm{x}}$ emission inventory was estimated from the census data and the emission factors cited from Kato and Akimoto (1992). The $\mathrm{SO}_{2}$ emission inventory was cited from the China Statistical Yearbook (2009). Both the $\mathrm{NO}_{\mathrm{x}}$ and $\mathrm{SO}_{2}$ emission inventories were allocated onto the most suitable land use type by the bottomup process. Primary census databases used for the estimation of emission inventories of $\mathrm{NH}_{3}$ and $\mathrm{NO}_{\mathrm{x}}$ were obtained from the China Statistical Yearbook (2009). The total emission of
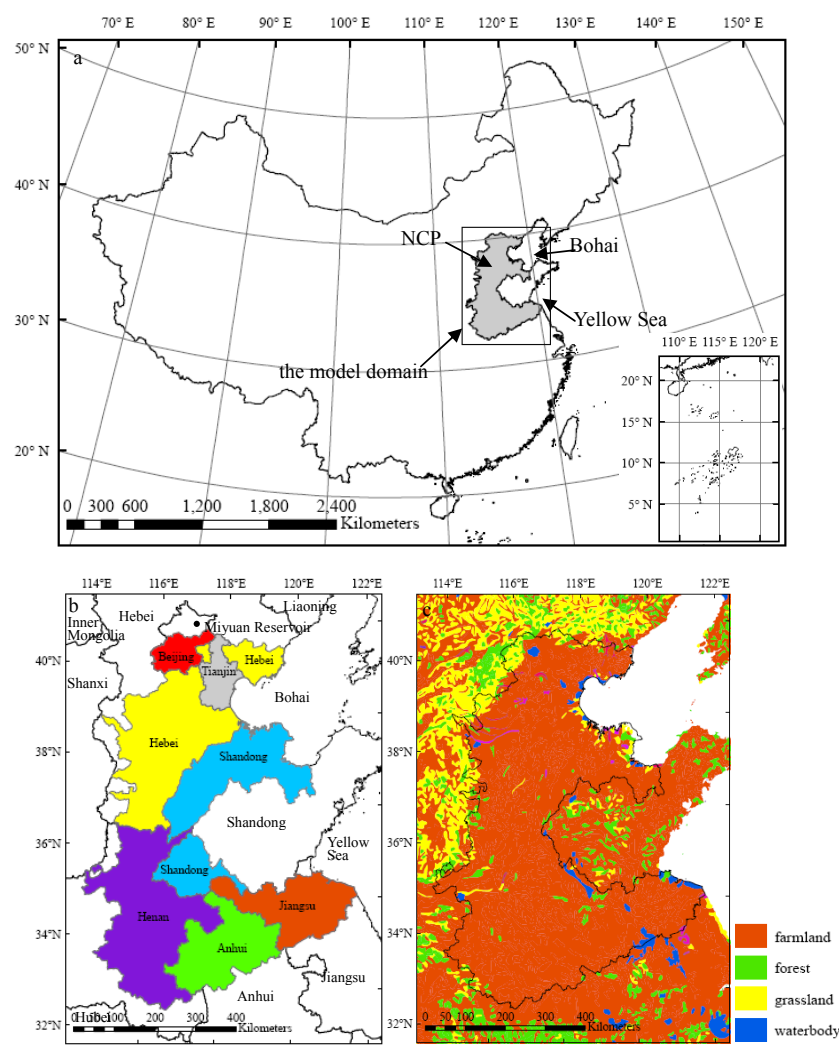

Fig. 1. The model domain and the NCP in China (a) the model domain and the NCP; (b) the provinces in the NCP; (c) land use in the NCP.

$\mathrm{NH}_{3}-\mathrm{N}$ for the model domain was $3500 \mathrm{Gg}, 15 \%$ higher than the result estimated $(3100 \mathrm{Gg})$ by REAS for the year 2003 and consistent with the result $(3300 \mathrm{Gg})$ projected by REAS for the year 2008 (REAS, 2006). Total emissions of $\mathrm{NO}_{\mathrm{x}}-\mathrm{N}$ and $\mathrm{SO}_{2}-\mathrm{S}$ for the model domain were $2000 \mathrm{Gg}$ and $4700 \mathrm{Gg}$, respectively, without significant differences among the results estimated by REAS, $2100 \mathrm{Gg} \mathrm{NO}_{\mathrm{x}}-\mathrm{N}$ and $5000 \mathrm{Gg} \mathrm{SO}_{2^{-}}$ $S$ for the year 2006 (CGRER, 2007).

Emissions of $\mathrm{NH}_{3}, \mathrm{NO}_{\mathrm{x}}$ and $\mathrm{SO}_{2}$ outside the $\mathrm{NCP}$ domain were taken from a national scale emissions map (cited from REAS database), gridded at $50 \mathrm{~km}$ resolution. Boundary conditions for air concentrations of aerosols for the regional (5 km resolution) NCP simulation were calculated with a larger scale simulation at $50 \mathrm{~km}$ resolution over the whole of China.

The wind roses employed in the FRAME model used 6-hourly operational radiosonde data from the 6 stations (Fig. 3), spanning a ten-year period (1997-2007) to establish the frequency and harmonic mean wind speed as a function of direction for the NCP. Radiosonde data were obtained from the British Atmospheric Data Centre (2008).

The precipitation and land use data employed in the model were published by the Institute of Geographic Sciences and 

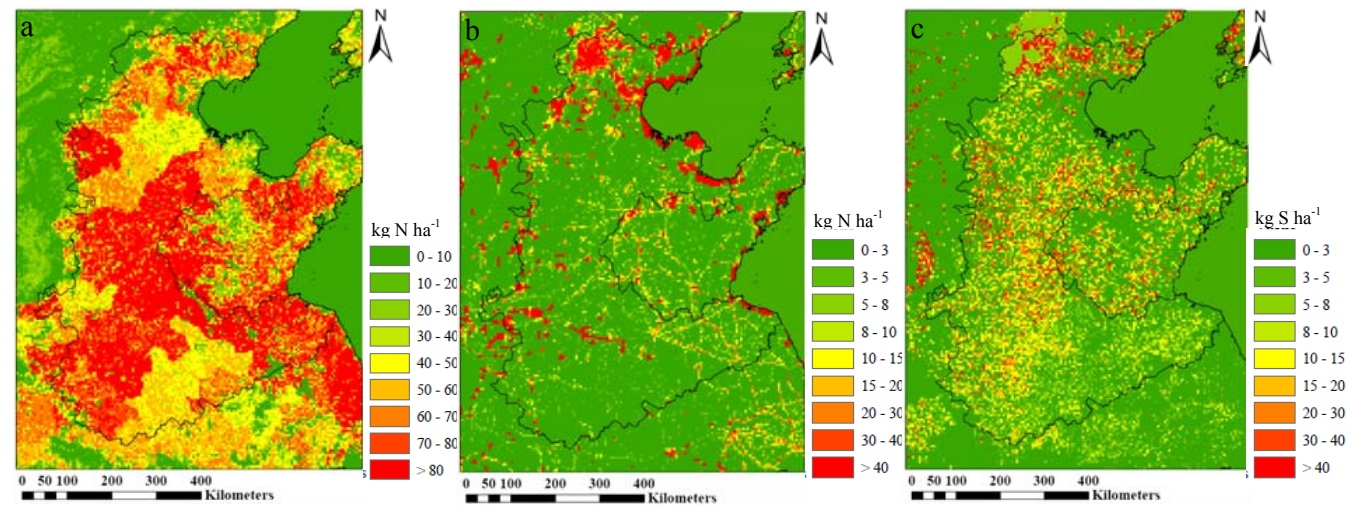

Fig. 2. Emissions of $\mathrm{NH}_{3}$ (a), $\mathrm{NO}_{\mathrm{y}}$ (b) and $\mathrm{SO}_{2}$ (c) in the NCP in the year 2008 .
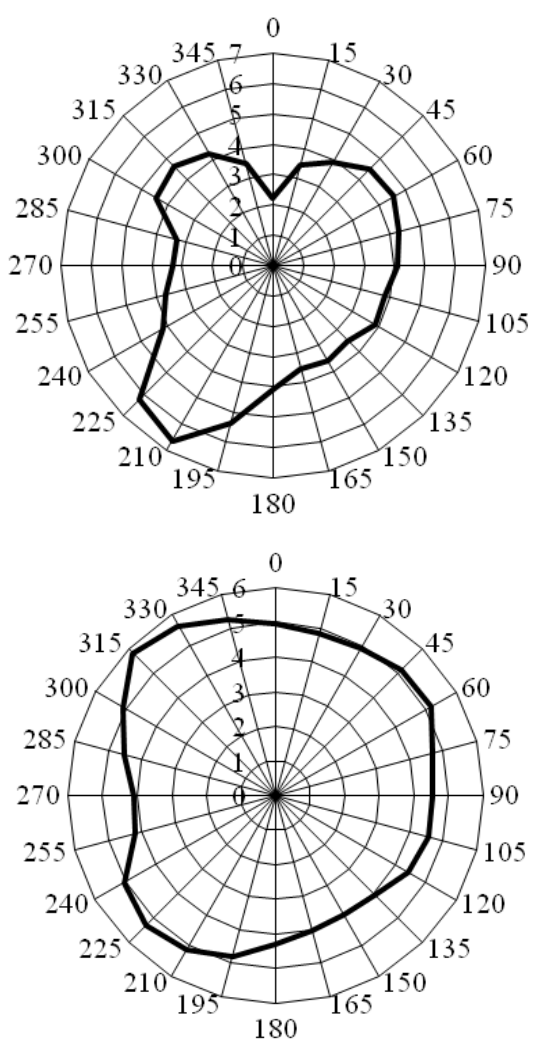

Fig. 3. Wind frequency rose (a) and wind speed rose (b) derived from radiosonde data in the North China Plain (Radiosonde data are from stations at Beijing, Fuyang, Jinan, Xuzhou and Zhengzhou) (a. Radial units are percent per $15^{\circ}$ directional band; $b$. wind speed. units are $\left.\mathrm{ms}^{-1}\right)$.

Natural Resources Research, Chinese Academy of Sciences. The original databases were at $1 \mathrm{~km}$ resolution and they were aggregated to $5 \mathrm{~km}$ resolution for input into the FRAME model of the NCP.

\subsection{Comparison between modeled and measured results}

A comparison with measurements from monitoring sites on the NCP was carried out to evaluate the performance of the model. Because of the lack of monitoring data of gases $\left(\mathrm{NH}_{3}\right)$ and aerosols $\left(\mathrm{NH}_{4}^{+}, \mathrm{NO}_{3}^{-}\right.$and $\left.\mathrm{HNO}_{3}\right)$, it was difficult to fully quantify the uncertainties from dry deposition. $\mathrm{NO}_{2}$ concentrations were only available at 13 monitoring sites in 2008 (China Statistical Yearbook, 2009). Measured wet deposition data were available at 13 monitoring sites in the NCP in 2008 (reduced N deposition at 13 sites and oxidized $\mathrm{N}$ deposition at 12 sites). Volume weighted annual mean concentrations of $\mathrm{NH}_{4}^{+}$and $\mathrm{NO}_{3}^{-}$from precipitation were selected to validate the model. With the present information, modeled $\mathrm{NH}_{4}^{+}, \mathrm{NO}_{3}^{-}$concentrations in precipitation and $\mathrm{NO}_{2}$ concentrations in air were compared against measured results for the year 2008 (Fig. 4), and the model evaluation statistics were listed in Table 3. Linear regressions with non-zero intercepts were conducted and displayed higher intercepts for $\mathrm{NH}_{4}^{+}$and $\mathrm{NO}_{3}^{-}$than those in the simulation in the UK (Dore et al., 2009), respectively, possibly related to fewer data distributed in the low concentration ranges in the NCP. Although the correlations were statistically significant $(p<0.05)$, they could not be claimed to explain the real situation. Linear regressions with zero intercepts were also conducted. In these comparisons, modeling results of $\mathrm{NH}_{4}^{+}$fitted the measured data well with a regression coefficient of 1.05 (Fig. 4a). However, modeling results for $\mathrm{NO}_{3}^{-}$were significantly underestimated with a regression coefficient of only 0.63 (Fig. 4b). Underestimation of measured nitrate wet deposition by models has also been reported by other authors (Dore et al., 2007; Chemel et al., 2010). The more complex chemical reactions associated with the formation of nitrate aerosol may mean that wet deposition of this chemical species is more difficult to simulate accurately than wet deposition of ammonium. Some dry deposition of nitric acid onto the surface of the rain collector may have occurred, though assessment of this has not been reported 

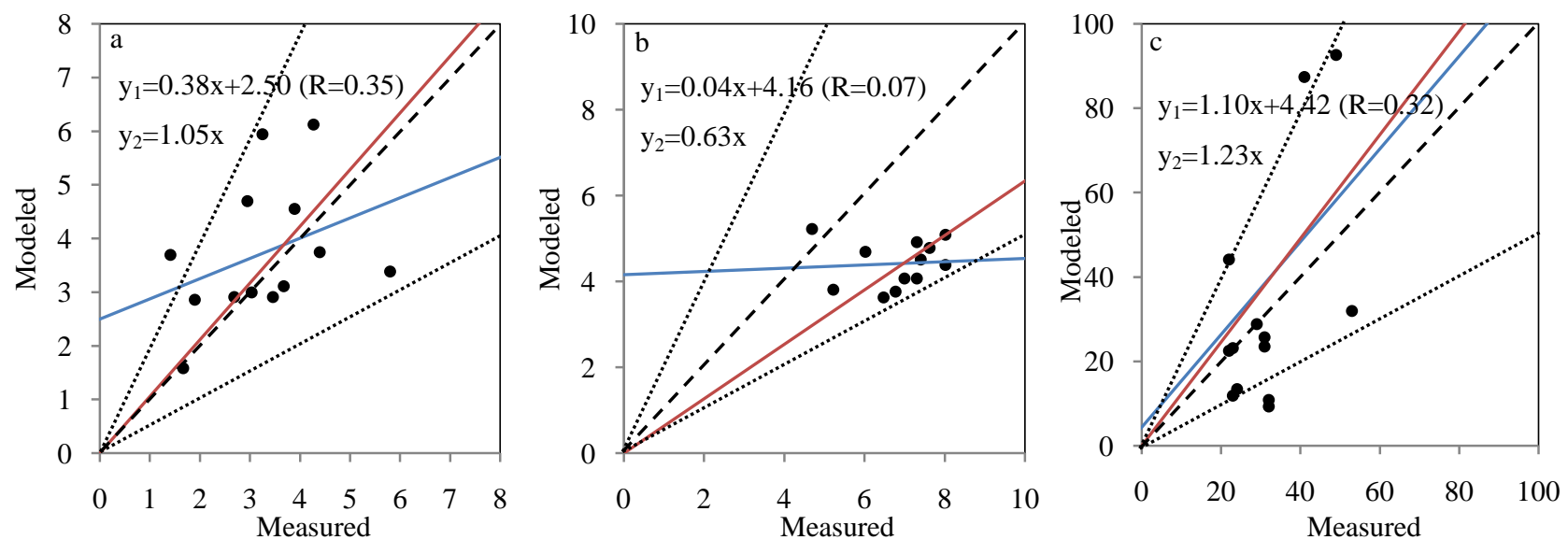

Fig. 4. Comparison of simulated concentrations of $\mathrm{NH}_{4}^{+}$in precipitation (a), $\mathrm{NO}_{3}^{-}$in precipitation (b) and $\mathrm{NO}_{2}$ in air (c) with measured data (units for $\mathrm{NH}_{4}^{+}$and $\mathrm{NO}_{3}^{-}$are $\mathrm{mg} \mathrm{L}^{-1}$; unit for $\mathrm{NO}_{2}$ is $\mu \mathrm{g} \mathrm{m}^{-3}$ ). (The dotted lines are 1:2 and 2:1 fit line, and the dashed line is 1:1 fit line. The red and blue solid lines are linear fit of zero intercept and non-zero intercept regressions, respectively.) A model is considered fit for purpose if more than $50 \%$ of the points fall within the 1:2 and 2:1 lines.

in the literature. Also, $\mathrm{N}$ deposition derived from shipping emissions of $\mathrm{NO}_{\mathrm{x}}$ was not included here. Relatively robust regressions were displayed for $\mathrm{NO}_{2}$ concentrations in both the regressions. Modeled concentrations of $\mathrm{NO}_{2}$ were higher than measured results with coefficients of 1.10 and 1.23 for the two regressions, respectively (Fig. 4c), which further supports the hypothesis for the underestimation of $\mathrm{NO}_{3}^{-}$concentration. Moreover, points located between 2:1 and 1:2 reference lines were analyzed. $92 \%$ of the model results for $\mathrm{NH}_{4}^{+}$were accordant within a factor of two times the measurements, $100 \%$ of modeled results for $\mathrm{NO}_{3}^{-}$were within a factor of two times the measurements, and $80 \%$ of modeled results for $\mathrm{NO}_{2}$ were within a factor of two times the measurements. A model is generally considered fit for purpose if more than $50 \%$ of the points fall within the $1: 2$ and 2:1 lines. Combined with the regression coefficient, this analysis implies that the FRAME model was effective in capturing the spatial variability of $\mathrm{N}$ deposition over the NCP.

\section{Results and discussion}

\subsection{Budget of $\mathrm{N}$ deposition in the NCP}

Budgets of $\mathrm{NH}_{\mathrm{x}}$ and $\mathrm{NO}_{\mathrm{y}}$ from dry and wet deposition over the NCP in the year 2008 were calculated by the FRAME model. Results for import, export, emission, and deposition of materials are listed separately in Table 1. In total, $1484 \mathrm{GgN}$ were deposited in this region from both dry and wet deposition, with an average $\mathrm{N}$ deposition of $47 \mathrm{~kg} \mathrm{Nha}^{-1} \mathrm{yr}^{-1}$. N deposition was previously calculated in both the UK and Poland by the same model (Dore et al., 2009; Kryza, 2009). It was calculated that the same budget for the UK in the year 2005 by FRAME was $319 \mathrm{Gg}$ (Dore et al., 2009). Compared to the result above, the total deposition of $\mathrm{N}$ in the NCP was 4.7 times that in the UK, while the area ratio of the NCP to the UK is only 1.3. Thus, the average $\mathrm{N}$ deposition rate at grid cell in the NCP was 3.6 times that in the UK. The $\mathrm{NH}_{\mathrm{x}}$ deposition budget for Poland calculated by the same model was $227 \mathrm{Gg} \mathrm{NH}_{\mathrm{x}}-\mathrm{N}$ in 2002 (Kryza, 2009). Modeled $\mathrm{NH}_{\mathrm{x}}-\mathrm{N}$ deposition was $1143 \mathrm{Gg}$ in the $\mathrm{NCP}$ in our study. Taking the area ratio of the two regions into account, the average deposition rate of $\mathrm{NH}_{\mathrm{X}}-\mathrm{N}$ at grid cell in the NCP was about 5 times that in Poland. The EMEP model calculated the total $\mathrm{N}$ deposition in the EU27 countries to be $3714 \mathrm{Gg}$ in the year 2008 (EMEP, 2011), equal to an average deposition rate of $8.6 \mathrm{~kg} \mathrm{~N} \mathrm{ha}^{-1} \mathrm{yr}^{-1}$ in the EU 27 countries and less than $20 \%$ of that in the NCP.

Reduced N deposition was higher than oxidized N deposition in the $\mathrm{NCP}$, illustrating higher $\mathrm{NH}_{3}$ emissions from agricultural sources than $\mathrm{NO}_{\mathrm{x}}$ emissions from industrial or traffic sources (Bouwman et al., 1997; Streets et al., 2000). Average $\mathrm{NH}_{\mathrm{x}}-\mathrm{N}$ to $\mathrm{NO}_{\mathrm{y}}-\mathrm{N}$ ratio was 3.4 with ratios less than 2.0 found only in the Beijing and Tianjin municipalities, which are more highly developed regions with more $\mathrm{NO}_{\mathrm{x}}$ emissions from traffic and industrial sources. The domination of $\mathrm{NH}_{\mathrm{x}}-\mathrm{N}$ was consistent with observed results (Lü and Tian, 2007). However, the lower oxidized $\mathrm{N}$ ratio did not correspond to less deposition than in other regions. Average $\mathrm{NO}_{\mathrm{y}}-$ $\mathrm{N}$ deposition was $11 \mathrm{~kg} \mathrm{Nha}^{-1} \mathrm{yr}^{-1}$, comparable to the modeled total $\mathrm{N}$ deposition in the UK (Dore et al., 2009). High tropospheric $\mathrm{NH}_{3}$ and $\mathrm{NO}_{2}$ concentrations over this region have been observed from space by remote sensing (Richter et al., 2005; Clarisse et al., 2009). Both the high $\mathrm{NH}_{\mathrm{x}}-\mathrm{N}$ and $\mathrm{NO}_{\mathrm{y}}-\mathrm{N}$ deposition rates may be attributed largely to China's rapidly developing economy, especially increased fertilizer $\mathrm{N}$ application and rapidly increasing energy consumption over recent years (China Statistical Yearbook, 2009). 
Table 1. Mass budgets of emission, import, export and deposition of $\mathrm{N}$ in the NCP.

\begin{tabular}{lllllllll}
\hline $\mathrm{N}$ species & $\begin{array}{l}\text { Import } \\
(\mathrm{Gg})\end{array}$ & $\begin{array}{l}\text { Emission } \\
(\mathrm{Gg})\end{array}$ & $\begin{array}{l}\text { Dry deposition } \\
(\mathrm{Gg})\end{array}$ & $\begin{array}{l}\text { Wet deposition } \\
(\mathrm{Gg})\end{array}$ & $\begin{array}{l}\text { Total deposition } \\
(\mathrm{Gg})\end{array}$ & $\begin{array}{l}\text { Sea deposition } \\
(\mathrm{Gg})\end{array}$ & $\begin{array}{l}\text { Export } \\
(\mathrm{Gg})\end{array}$ & $\begin{array}{l}\text { Export/Import } \\
\text { ratio }\end{array}$ \\
\hline $\mathrm{NH}_{\mathrm{x}}-\mathrm{N}$ & 283 & 2346 & 316 & 827 & 1143 & 278 & 1206 & 4.27 \\
$\mathrm{NO}_{\mathrm{y}}-\mathrm{N}$ & 301 & 899 & 150 & 190 & 340 & 82 & 776 & 2.58 \\
Total-N & 584 & 3245 & 466 & 1018 & 1484 & 360 & 1981 & 3.40 \\
\hline
\end{tabular}

a

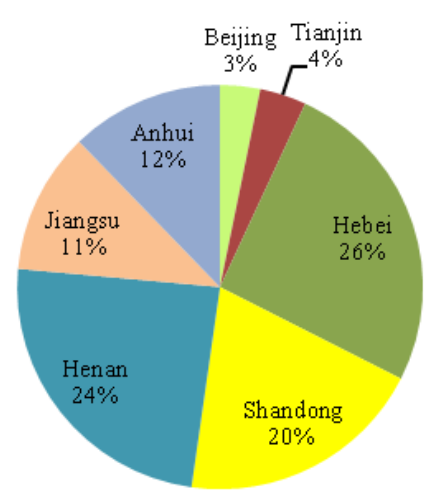

b

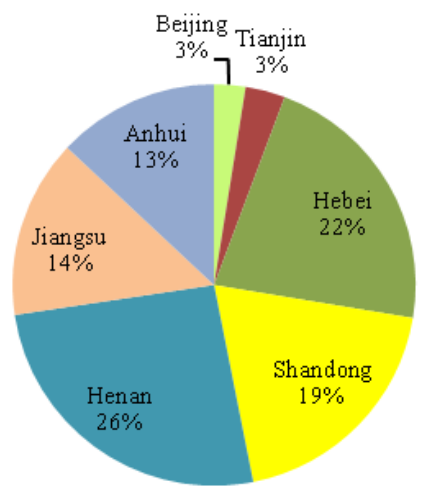

Fig. 5. Contributions of areas (a) and $\mathrm{N}$ deposition budgets (b) in the NCP at province level (only the areas and $\mathrm{N}$ deposition budgets of the seven provinces within the NCP were included; areas and N deposition budgets of the seven provinces outside the NCP were omitted).

High N deposition was not restricted to the NCP, but also influenced the surrounding area by the long-distance transportation of N-compound pollutants. The exported N component $(1981 \mathrm{Gg}$ ) was 3.4 times the imported $\mathrm{N}$ component $(584 \mathrm{Gg})$, demonstrating the important pollution source effect of the NCP. Of the total N deposition budget in the NCP, $22 \%, 19 \%, 26 \%, 14 \%, 13 \%, 3 \%$ and $3 \%$ were derived from Hebei, Shandong, Henan, Jiangsu, Anhui, Beijing and Tianjin, respectively. Contributions to the $\mathrm{N}$ deposition budgets from the seven provinces were nearly proportional to the area percentages of the individual provinces to the NCP (Fig. 5).

\subsection{Spatial distribution of $\mathrm{N}$ deposition in the NCP}

Emitted N-compounds are deposited onto terrestrial and aquatic surfaces in the form of dry and wet deposition. Chemical reactions take place in the atmosphere in both the aqueous and dry phases, and species of $\mathrm{NH}_{3}, \mathrm{NH}_{4}^{+}, \mathrm{NO}$, $\mathrm{NO}_{2}, \mathrm{NO}_{3}^{-}$, PAN and $\mathrm{HNO}_{3}$ are produced during the emission, transport and deposition processes (S-compounds are also produced but not discussed here). Concentrations of $\mathrm{N}$ compounds, $\mathrm{NH}_{3}, \mathrm{NH}_{4}^{+}, \mathrm{NO}_{\mathrm{x}}, \mathrm{NO}_{3}^{-}$and $\mathrm{HNO}_{3}$, and deposition rates of reduced and oxidized $\mathrm{N}$ from dry and wet deposition are mapped at $5 \times 5 \mathrm{~km}^{2}$ resolution in Figs. 6 and 7.
The distribution of the modeled $\mathrm{NH}_{3}$ concentration was correlated to the distribution of $\mathrm{NH}_{3}$ emission (Figs. 2a and 6a), which can be attributed to the short-distance transport of $\mathrm{NH}_{3}$ (Asman et al., 1998). In contrast to $\mathrm{NH}_{3}$, emitted $\mathrm{NO}_{2}$ has a longer lifetime and deposition occurs far from the sources. Hotspots of the $\mathrm{NO}_{2}$ emissions extended to larger areas by long-distance transport, resulting in greater regions, even the coastal regions, sharing higher gaseous $\mathrm{NO}_{2}$ concentrations (Fig. 6b). $\mathrm{NH}_{4}^{+}$and $\mathrm{NO}_{3}^{-}$ions are mostly formed through gas to aerosol conversion forming fine $\left(\mathrm{NH}_{4}\right)_{2} \mathrm{SO}_{4}$, $\mathrm{NH}_{4} \mathrm{HSO}_{4}$ and $\mathrm{NH}_{4} \mathrm{NO}_{3}$ particles. These aerosols are removed principally by wet deposition. Relatively higher concentrations of aerosol $\mathrm{NH}_{4}^{+}$and $\mathrm{NO}_{3}$ were found in the northern area where lower precipitation and reduced aerosol removal rates occur (Fig. 6c, d). Higher concentrations of $\mathrm{HNO}_{3}$ were distributed in the areas with lower $\mathrm{NH}_{3}$ concentration, while lower concentration of $\mathrm{HNO}_{3}$ occurred in the areas with higher $\mathrm{NH}_{3}$ concentration (Fig. 6e). This can be explained by the increased production of $\mathrm{NH}_{4} \mathrm{NO}_{3}$ from the gaseous precursors $\mathrm{NH}_{3}$ and $\mathrm{HNO}_{3}$.

The dry deposition rates of reduced and oxidized $\mathrm{N}$ were associated with both their concentrations and their deposition velocities. The dry deposition of reduced $\mathrm{N}$ exhibited higher rates in areas around rather than within the NCP (Fig. 7a), which could be attributed to land use (Fig. 1c). The NCP is an intensive agricultural region dominated by farmland, whereas it is surrounded by mountains in the west and the 

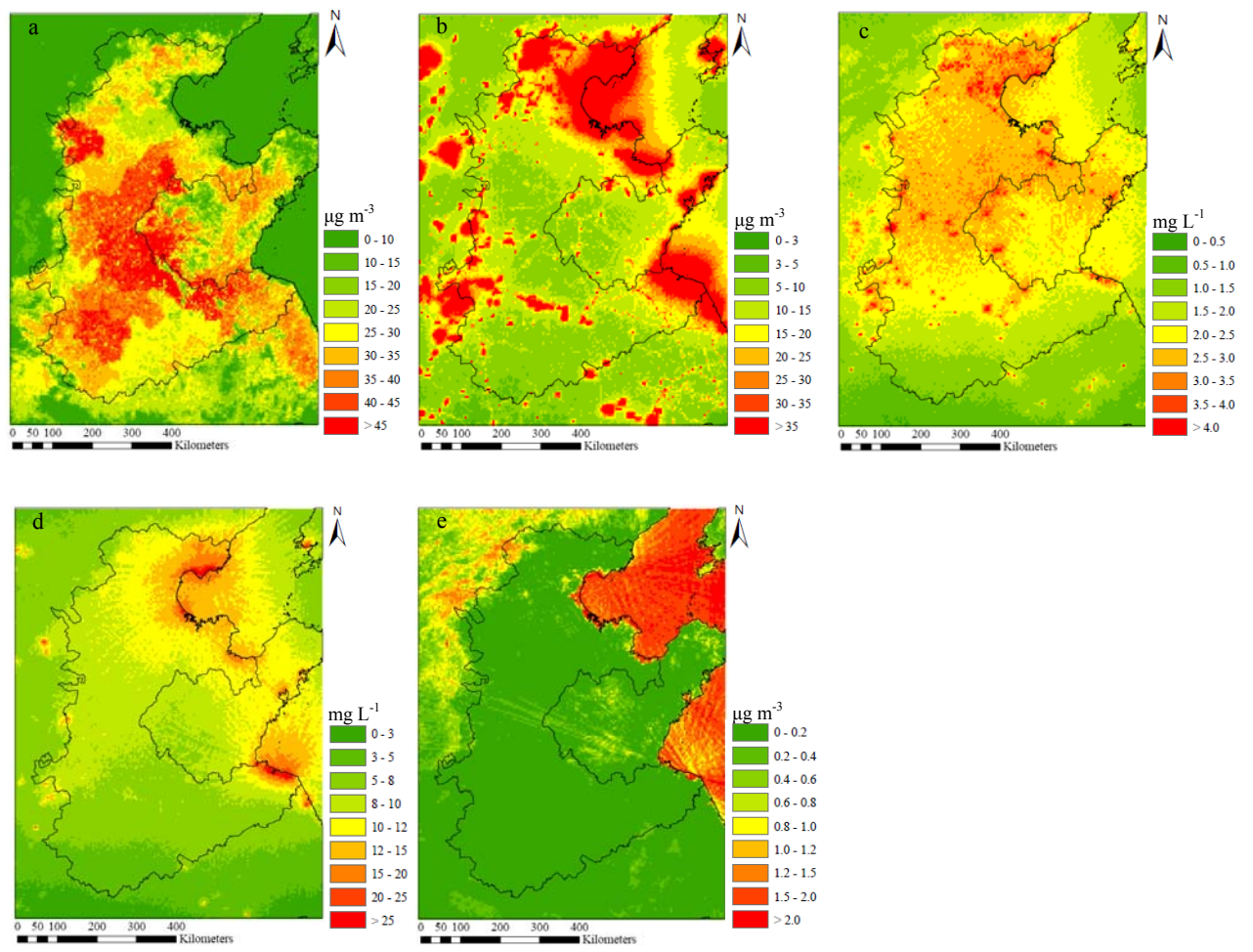

Fig. 6. Modeled concentrations of $\mathrm{N}$-containing pollutants in the $\mathrm{NCP}$ in 2008 at $5 \times 5 \mathrm{~km}^{2}$ resolution $\left(\mathrm{a} . \mathrm{NH}_{3}\right.$; b. $\mathrm{NO}_{\mathrm{x}} ; \mathrm{c}$. $\mathrm{NH}_{4}^{+}$; d. $\mathrm{NO}_{3}^{-}$; e. $\mathrm{HNO}_{3}$ ).
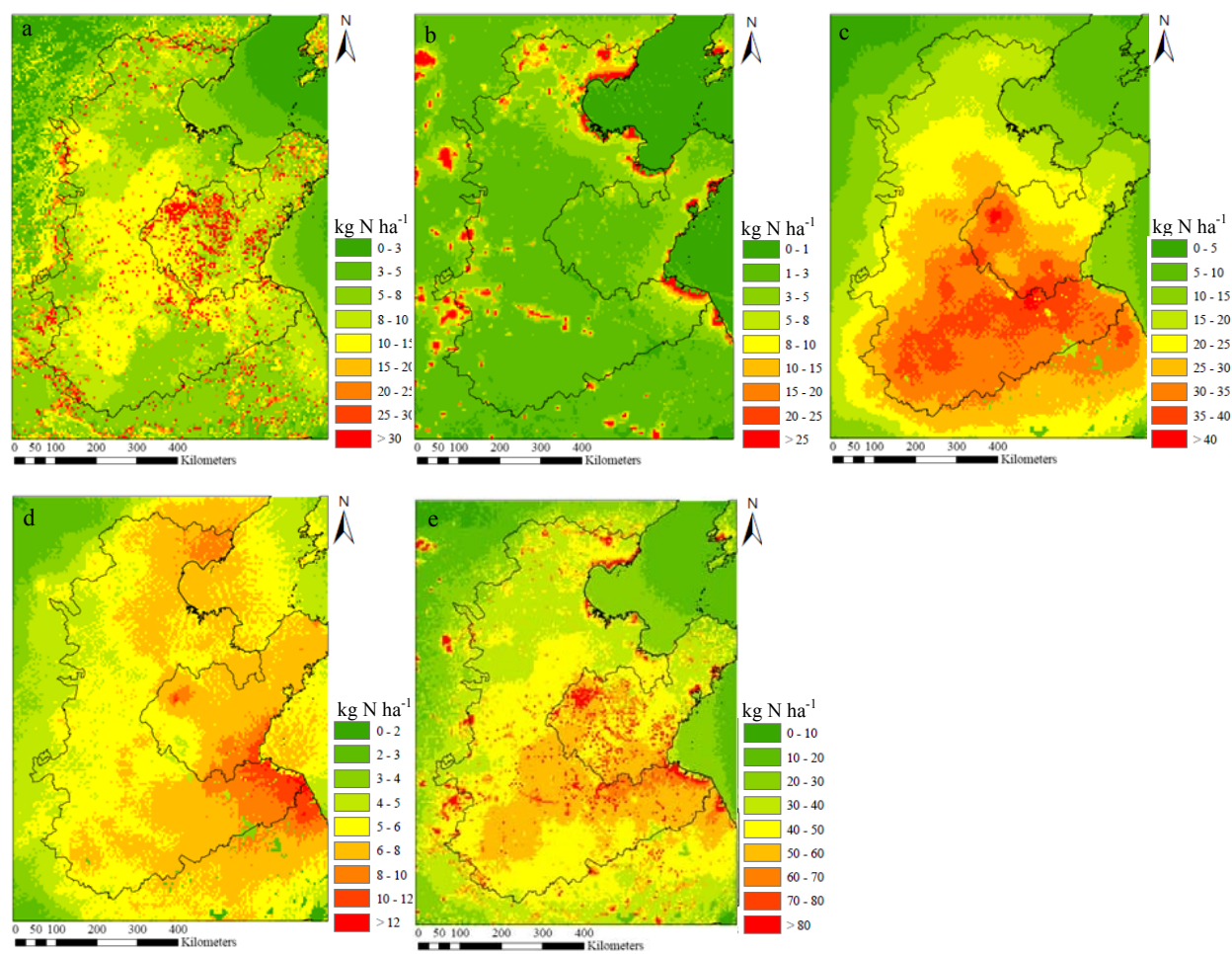

Fig. 7. Modeled deposition of $\mathrm{N}$-containing pollutants in the $\mathrm{NCP}$ in 2008 at $5 \times 5 \mathrm{~km}^{2}$ resolution $\left(\mathrm{a} . \mathrm{NH}_{\mathrm{x}}\right.$-dry; b. $\mathrm{NO}_{\mathrm{y}}$-dry; c. $\mathrm{NH}_{\mathrm{x}}$-wet; d. $\mathrm{NO}_{\mathrm{y}}$-wet; e. N-total). 
north with forest and grassland. $\mathrm{NH}_{3}$ deposition velocity is connected with bulk canopy resistance varying with vegetation. Bulk canopy resistance increases in regions of farmland and improved grassland, causing dry deposition velocity decreases (Singles et al., 1998; Smith et al., 2000). This explains the higher dry deposition of reduced $\mathrm{N}$ at the western and northern boundaries. With less influence from land use, oxidized $\mathrm{N}$ deposition was better correlated to the $\mathrm{NO}_{2}$ concentration (Figs. 2b and 7b). High deposition rates of reduced $\mathrm{N}$ and oxidized $\mathrm{N}$ occurred in the south and the east, respectively (Fig. 7c, d), attributed to both the high aerosol concentrations and the high precipitation. The total $\mathrm{N}$ deposition is illustrated in Fig. 7e. Total $\mathrm{N}$ deposition in the NCP at $5 \times 5 \mathrm{~km}^{2}$ cell grid generally ranged from 20 to $80 \mathrm{~kg} \mathrm{Nha}^{-1} \mathrm{yr}^{-1}$. Hotspots appeared in the southern NCP with $\mathrm{N}$ deposition higher than $80 \mathrm{~kg} \mathrm{Nha}^{-1} \mathrm{yr}^{-1}$, consistent with the global spatial distribution of $\mathrm{N}$ deposition (Dentener et al., 2006).

\subsection{Comparison between modeling results and observations}

The modeled averages of $\mathrm{N}$ wet and dry deposition were 32 and $15 \mathrm{~kg} \mathrm{Nha}^{-1} \mathrm{yr}^{-1}$, respectively. Wet $\mathrm{N}$ deposition was consistent with results in the NCP in the 2000s (Zhang et al., 2008). However, dry deposition of $\mathrm{N}$ was much lower than results obtained from monitoring results (Shen et al., 2009). Such difference could be attributed by following reasons. Firstly, no measured deposition velocities of gases and aerosols have been available in this region until now. Shen et al. (2009) cited much higher deposition velocities than those applied in the FRAME model (Table 2). Secondly, $\mathrm{NH}_{3}$ is a bi-directional exchange species and only net fluxes were considered in the model, which may underestimate the $\mathrm{N}$ dry deposition because the model did not distinguish between the two deposition and emission processes for $\mathrm{NH}_{3}$. Shen et al. (2009) used a simple $\mathrm{NH}_{3}$ compensation point $\left(5 \mu \mathrm{g} \mathrm{N} \mathrm{m}{ }^{-3}\right)$ value to estimate dry deposition of reactive $\mathrm{N}$ species (assuming dry deposition occurred only when $\mathrm{NH}_{3}$ concentration was higher than $5 \mu \mathrm{g} \mathrm{N} \mathrm{m}^{-3}$ ) in their calculation, which may also lead to some uncertainties due to the absence of a stable $\mathrm{NH}_{3}$ compensation point during the winter wheat and summer maize double cropping system. Therefore there is some need to improve both the monitoring and the simulation of $\mathrm{N}$ dry deposition in the NCP.

\subsection{Potential exceedances}

High $\mathrm{N}$ concentration was found in the NCP, at a level which is known to cause adverse effects to ecosystems by acidification and eutrophication in the North America and Europe in spite of few studies of critical levels available in this region until now. Cape et al. (2009) reviewed the critical level of $\mathrm{NH}_{3}$, proposing $1 \mu \mathrm{g} \mathrm{m}^{-3}$ for bryophytes and lichens and $3 \mu \mathrm{g} \mathrm{m}^{-3}$ for all other plant species instead of the
Table 2. Dry deposition velocities of N-compound pollutants cited in Shen et al. (2009) and in the FRAME model (unit: $\mathrm{mm} \mathrm{s}^{-1}$ )

\begin{tabular}{|c|c|c|}
\hline Species & $\begin{array}{c}\text { Value cited by } \\
\text { Shen et al., } 2009\end{array}$ & $\begin{array}{l}\text { Value used in } \\
\text { the FRAME model }\end{array}$ \\
\hline $\mathrm{NH}_{3}$ & 7.4 & $\begin{array}{c}\text { Canopy resistance calculation } \\
\text { (Smith et al., 2000) }\end{array}$ \\
\hline $\mathrm{NO}_{2}$ & 5.9 & $\begin{array}{l}\text { Vegetation specific } \\
\text { (Smith et al., 2000) }\end{array}$ \\
\hline $\mathrm{HNO}_{3}$ & 20 & 30 \\
\hline $\mathrm{NH}_{4}^{+}$ & 2.4 & 1 \\
\hline $\mathrm{NO}_{3}^{-}$ & 2.4 & 1 \\
\hline
\end{tabular}

Table 3. Model evaluation statistics for $\mathrm{NH}_{4}^{+}, \mathrm{NO}_{3}^{-}$and $\mathrm{NO}_{2}$ concentrations.

\begin{tabular}{ccccccccc}
\hline Species & $\mathrm{n}$ & FAC2 & MB & MGE & NMB & NMGE & RMSE & $\mathrm{r}$ \\
\hline $\mathrm{NH}_{4}^{+}$ & 13 & 0.92 & 0.47 & 1.13 & 0.14 & 0.35 & 1.45 & 0.35 \\
$\mathrm{NO}_{3}^{-}$ & 12 & 1.00 & -2.41 & 2.50 & -0.35 & 0.37 & 7.00 & 0.07 \\
$\mathrm{NO}_{2}$ & 13 & 0.77 & 1.00 & 16.35 & 0.03 & 0.52 & 21.98 & 0.30 \\
\hline
\end{tabular}

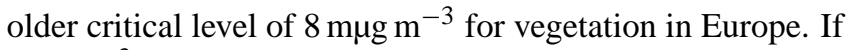
$3 \mu \mathrm{g} \mathrm{m}^{-3}$ was applied in our study, ammonia concentrations in $99.3 \%$ of the areas in the NCP would exceed the critical level (Fig. 8a). Bobbink et al. (2010) summarized empirical critical loads for various terrestrial ecosystems in Europe and the US with a range of $5-30 \mathrm{~kg} \mathrm{Nha}^{-1} \mathrm{yr}^{-1}$ for forests and grasslands. Experiments in temperate deciduous forests and temperate grasslands in China showed similar critical loads of $10-30 \mathrm{~kg} \mathrm{~N} \mathrm{ha}^{-1} \mathrm{yr}^{-1}$ (Pan et al., 2005; Zhao et al., 2008). Even taking the upper limit, $\mathrm{N}$ deposition in $99.7 \%$ of the areas of the NCP exceeded the critical load (Fig. 8b).

However, the NCP is an intensive agricultural area dominated by farmland which is nutrient tolerant. Liu et al. (2011) estimated and mapped critical loads in China based on the steady state mass balance (SSMB) method and data from the literature, which resulted in a very high critical load, more than $200 \mathrm{~kg} \mathrm{~N} \mathrm{ha}^{-1} \mathrm{yr}^{-1}$, for the agricultural area in the NCP. As $92 \%$ of the area is arable land in the NCP (including overlaps with forest, grassland and urban areas), this indicates that $\mathrm{N}$ deposition in nearly all the areas was under the critical limit, in complete contrast to initial calculations with exceedances estimation at a critical load of $30 \mathrm{~kg} \mathrm{Nha}^{-1} \mathrm{yr}^{-1}$. However, this does not suggest that the current $\mathrm{N}$ deposition level in the NCP is completely safe. First of all, the critical loads and exceedances discussed above were based on a theoretical calculation. The cereal and vegetable crops have a high tolerance of eutrophication and the calcareous soil in the NCP has a high tolerance of acidification. The properties of both vegetation and soil determined the high critical load. Actually, agricultural ecosystems in the NCP had already been artificially $\mathrm{N}$ saturated with excessive $\mathrm{N}$ 

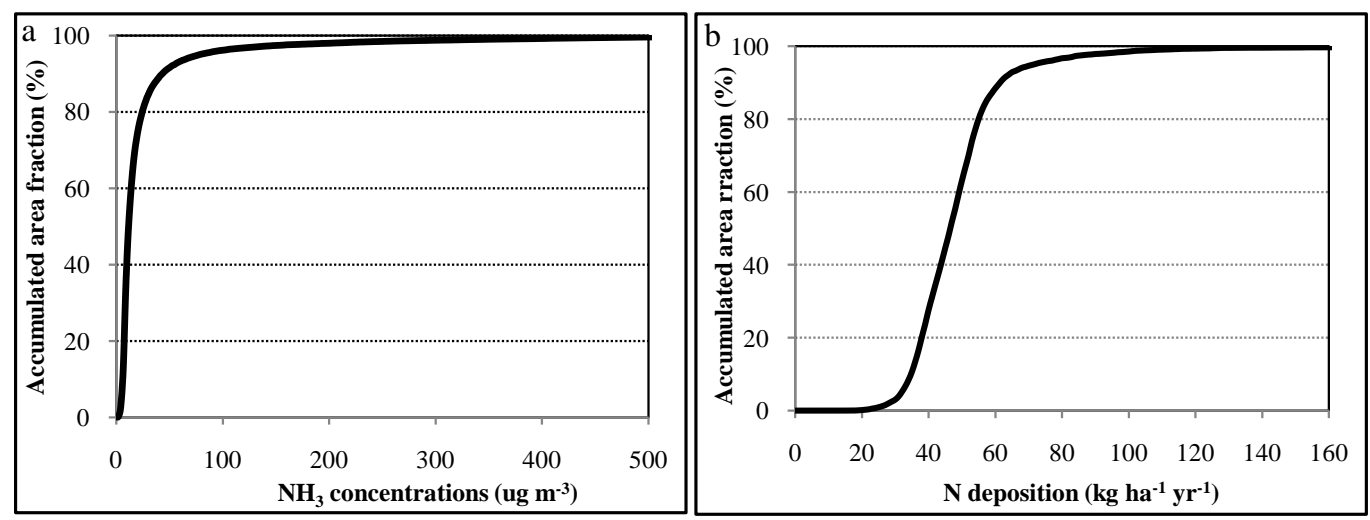

Fig. 8. Accumulated area fraction of grid cell $\mathrm{NH}_{3}$ concentration (a) and $\mathrm{N}$ deposition (b) in the NCP in 2008.

accumulation, nitrate leaching, ammonia volatilization and $\mathrm{N}_{2} \mathrm{O}$ emissions (Ju et al., 2009). The simulated critical load of $\mathrm{N}, 200 \mathrm{~kg} \mathrm{Nha}^{-1} \mathrm{yr}^{-1}$, was a safe value consistent with the optimum total $\mathrm{N}$ inputs in the agricultural ecosystems in the NCP rather than a real critical load of $\mathrm{N}$ deposition in this region. Actual $\mathrm{N}$ fertilizer application rate in the NCP is double or triple the optimum value for the agroecosystems (Zhao et al., 1997). Even the lowest $\mathrm{N}$ deposition (17 kg N ha ${ }^{-1} \mathrm{yr}^{-1}$ in the simulation in this study) would still further stimulate environmental pollution related to reactive $\mathrm{N}$. In addition, natural regions surrounding the NCP were exposed to high $\mathrm{N}$ deposition for the diffusion of nitrogenous pollutants from intensive emission sources, e.g. Miyun Reservoir, a protected area for the drinking water source of Beijing (Fig. 1b), the total $\mathrm{N}$ concentration of the water was around $1.0 \mathrm{mg} \mathrm{L}^{-1}$ in 2000s (China Environmental Statistical Yearbook), which would be enriched even only the wet $\mathrm{N}$ deposition was taken into consideration (Fig. 7).

Moreover, the high concentrations of $\mathrm{N}$ pollutants in the atmosphere contributed to reduced visibility, regional haze, reaction with $\mathrm{O}_{3}$, formation of photochemical smog and health impacts associated with fine particulate matter (PM) (He et al., 2002; Chan and Yao, 2008). In the modeled results, the annual concentration of $\mathrm{NO}_{\mathrm{x}}$ in $4 \%$ of the total areas exceeded the critical level $\left(40 \mu \mathrm{g} \mathrm{m}^{-3}\right.$ for $\left.\mathrm{NO}_{2}\right)$ in the World Health Organization Air Quality Guidelines (2005). There is no special critical level of $\mathrm{NH}_{3}$ outlined for air quality, but it neutralizes acidic pollutants as a key precursor and produces fine particulate materials such as $\mathrm{NH}_{4} \mathrm{HSO}_{4}$, $\left(\mathrm{NH}_{4}\right)_{2} \mathrm{SO}_{4}, \mathrm{NH}_{4} \mathrm{NO}_{3}$, and $\mathrm{NH}_{4} \mathrm{Cl}$. The concentrations of $\mathrm{PM}_{2.5}$ were around $100 \mu \mathrm{g} \mathrm{m}^{-3}$ in Beijing in the 2000s, with a large contribution (22-54\%) from ammonium, nitrate and sulfate (He et al., 2003). De Leeuw and Horálek (2009) estimated that annual average $\mathrm{PM}_{2.5}$ concentration was range from 11.7 to $12.9 \mathrm{\mu g} \mathrm{m}^{-3}$ in the EU 27 countries in 2005 , causing 492000 premature deaths. Although there is no air quality impacts on human health data available in China, potential risks must have been happened already at such high $\mathrm{PM}_{2.5}$ concentrations and contributions from nitrogenous pollutants. More importantly, $\mathrm{NH}_{3}$ and $\mathrm{NO}_{\mathrm{x}}$ emissions in China kept increasing in the last three decades without any downward trend observed by now (Reis et al., 2009; Liu et al., 2011). And it is much more difficult to depress the concentrations of $\mathrm{NH}_{3}$ than the concentrations of $\mathrm{NO}_{\mathrm{x}}$, e.g. the $\mathrm{NO}_{\mathrm{x}}$ emissions were significantly lowered (Wang et al., 2010) but there was no significant decrease in the $\mathrm{NH}_{3}$ concentrations in Beijing during the 2008 Olympic Games (Shen et al., 2011).

Last but not least, high $\mathrm{N}$ deposition affected not only the terrestrial ecosystems but also the offshore regions. In the export budget, $18 \%$ of the $\mathrm{N}$ was deposited onto the coastal region (Table 1), corresponding to $22 \mathrm{~kg} \mathrm{~N} \mathrm{ha}^{-1}$ being directly deposited to the surface. Assuming that the total $\mathrm{N}$ deposition in the coastal region originates from precipitation, the volume weighted $\mathrm{N}$ concentration was as high as $4.4 \mathrm{mg} \mathrm{L}^{-1}$ in our studies. It was reported that the inorganic $\mathrm{N}$ concentration of the seawater in the coastal regions ranged from 0.002 to $5.310 \mathrm{mg} \mathrm{L}^{-1}, 0.308 \mathrm{mg} \mathrm{L}^{-1}$ on average, with $27.5 \%$ of samples exceeding the critical level $\left(0.3 \mathrm{mg} \mathrm{L}^{-1}\right)$ in 2008 (Coastal Environmental Quality Yearbook, 2008). The difference in the inorganic $\mathrm{N}$ concentrations between rainwater and seawater indicates that precipitation greatly enriched the $\mathrm{N}$ concentration of the seawater. $\mathrm{N}$ deposition derived from shipping emissions of $\mathrm{NO}_{\mathrm{x}}$ was not included here. This has been demonstrated to be highly significant in other regions (Dore et al., 2007). If these emissions were taken into account, the $\mathrm{N}$ concentration and deposition would be even higher than the current modeled results. According to data published by the State Oceanic Administration, there were 79 red tides on average in the year 2000s, while there was only one every five year in the 1960s. Kim et al. (2011) reported that significant increasing $\mathrm{N}$ abundance driven by $\mathrm{N}$ deposition in the Northwestern Pacific Ocean, especially in the East China Sea. As the simulated results in this study, high $\mathrm{N}$ deposition has become one of the main contributors to coastal eutrophication in China. 


\section{Conclusions}

Simulation of atmospheric N deposition in the NCP, a global hotspot for $\mathrm{N}$ deposition, was undertaken using the FRAME model for the first time at a much higher resolution $\left(5 \times 5 \mathrm{~km}^{2}\right)$ than previous studies in China. The total $\mathrm{N}$ deposition budget was $1481 \mathrm{Gg}$ in this region, with $77 \%$ from reduced $\mathrm{N}$ and $23 \%$ from oxidized $\mathrm{N}$. The average grid square deposition of $47 \mathrm{~kg} \mathrm{Nha}^{-1} \mathrm{yr}^{1}$ was 3-5 times higher than values obtained for European countries. The exported $\mathrm{N}$ budget $(1981 \mathrm{Gg}$ ) was much higher than the imported $\mathrm{N}$ budget $(584 \mathrm{Gg})$, suggesting that the NCP is an important net emission source of $\mathrm{N}$ pollutants. The calculated spatial distributions of $\mathrm{N}$ deposition displayed high rates of reduced $\mathrm{N}$ deposition in the south and of oxidized $\mathrm{N}$ deposition in the east. The $\mathrm{N}$ deposition exceeded an upper limit of $30 \mathrm{~kg} \mathrm{~N} \mathrm{ha}^{-1}$ for critical loads for natural ecosystems in more than $90 \%$ of the region and the critical level for ammonia concentrations of $3 \mu \mathrm{g} \mathrm{m}^{-3}$ for all plant species was also exceeded in over $90 \%$ of the region. High concentration of nitrogenous pollutants impaired air quality and threatened human health even without available assessments available by now. At the same time it resulted in coastal eutrophication not only in the NCP itself but also in surrounding areas including Miyun reservoir, the Bohai Sea and the Yellow Sea. Future work to improve spatially disaggregated estimates of $\mathrm{N}$ deposition in the NCP will focus on refining techniques to spatially map emissions of $\mathrm{NH}_{3}$ and $\mathrm{NO}_{\mathrm{x}}$ (and including emissions from international shipping) and expansion of monitoring networks for gas and aerosol concentrations and wet deposition of $\mathrm{N}$ compounds. Moreover, we recommend future studies with the application of Eulerian models with detailed dynamic meteorology and more complex atmospheric chemistry to estimate $\mathrm{N}$ deposition in the NCP.

Acknowledgements. This work was supported by the Innovative Group Grant from NSFC (30821003) and the National Natural Science Foundation of China (41071151). The authors acknowledge John Neil Cape in Centre for Ecology \& Hydrology, Edinburgh and Peter Christie of the Agri-Food and Biosciences Institute in Belfast for their valuable comments on this manuscript.

Edited by: S. Reis

\section{References}

Asman, W. A. H., Sutton, M. A., and Schjørring, J. K.: Ammonia: emission, atmospheric transport and deposition, New Phytol., 139, 27-48, 1998.

Bobbink, R., Galloway, H. J., Spranger, T., Alkemade, R., Ashmore, M., Bustamante, M., Cinderby, S., Davidson, E., Dentener, F., Emmett, B., Erisman, J.-W., Fenn, M., Gillian, F., Nordin, A., Pardo, L., and De Vries, W.: Global assessment of nitrogen deposition effects on terrestrial plant diversity: a synthesis, Ecol. Appl., 20, 30-59, 2010.
Bouwman, A. F., Lee, D. S., Asman, W. A. H., Dentener, F. J., Van Der Hoek, K. W., and Olivier, J. G. J.: A global high-resolution emission inventory for ammonia, Glob. Biogeochem. Cy., 11, 561-587, 1997.

British Atmospheric Data Centre (http://badc.nerc.ac.uk/home/ index.html), 2008.

Cape, J. N., van der Eerden, L. J., Sheppard, L. J., Leith, I. D., and Sutton, M. A.: Evidence for changing the critical level for ammonia, Environ. Pollut., 157, 1033-1037, 2009.

Castro, M. S. and Driscoll, C. T.: Atmospheric nitrogen deposition to estuaries in the Mid-Atlantic and Northeastern United States, Environ. Sci. Technol., 36, 3242-3249, 2002.

CGRER (http://www.cgrer.uiowa.edu/EMISSION_DATA_new/ index_16.html), 2007.

Chan, C. K. and Yao, X.: Air pollution in mega cities in China, Atmos. Environ, 42, 1-42, 2008.

Chemel, C., Sokhi, R. S., Yu, Y., Hayman, G. D., Vincent, K. J., Dore, A. J., Tang, Y. S., Parin, H. D., and Fisher, B. R. A.: Evaluation of a CMAQ simulation at high resolution over the UK for the calendar year 2003, Atmos. Environ., 44, 2927-2939, 2010.

China Environmental Statistical Yearbook (http://english.mep.gov. cn/standards_reports/EnvironmentalStatistics/), 2011.

China Statistical Yearbook 2009 (http://www.stats.gov.cn/tjsj/ndsj/ 2009/indexch.htm), 2011.

Clarisse, L., Clerbaux, C., Dentener, F., Hurtmans, D., and Coheur, P.: Global ammonia distribution derived from infrared satellite observations, Nat. GeoSci., 2, 479-483, 2009.

Coastal Environmental Quality Yearbook 2008 (http://jcs.mep.gov. cn/hjzl/jagb/2008jagb/201004/P020100414392998090995.pdf), 2010 (in Chinese).

De Leeuw, F. and Horálek, J.: Assessment of the Health impacts of exposure to $\mathrm{PM}_{2.5}$ at a European level, ETC/ACC technical paper No. 2009/1, 2009.

Dentener, F., Stevenson, D., Ellingsen, K., van Noije, T., Schultz, M., Amann, M., Atherton, C., Bell, N., Bergmann, D., Bey, I., Bouwman, L., Butler, T., Cofala, J., Collins, B., Drevet, J., Doherty, R., Eickhout, B., Eskes, H., Fiore, A., Gauss, M., Hauglustaine, D., Horowitz, L., Isaksen, I. S. A., Josse, B., Lawrence, M., Krol, M., Lamarque, J. F., Montanaro, V., Müller, J. F., Peuch, V. H., Pitari, G., Pyle, J., Rast, S., Rodriguez, J., Sanderson, M., Savage, N. H., Shindell, D., Strahan, S., Szopa, S., Sudo, K., van Dingernen, R., Wild, O., and Zeng, G.: The global atmospheric environment for the next generation, Environ. Sci. Technol., 40, 3586-3594, 2006.

Dore, A. J., Vieno, M., Tang, Y. S., Dragosits, U., Dosio, A., Weston, K. J., and Sutton, M. A.: Modeling the atmospheric transport and deposition of sulphur and nitrogen over the United Kingdom and assessment of the influence of $\mathrm{SO}_{2}$ emission from the international shipping, Atmos. Environ., 41, 2355-2367, 2007.

Dore, A. J., Kryza, M., Hallsworth, S., Matejko, M., Vieno, M., van Oijen, M., Zhang, Y., Smith, R., and Sutton, M.: Modelling the deposition and concentration of long range air pollutants: final report, Centre for Ecology \& Hydrology, Edinburgh, 2009.

EDGAR (http://edgar.jrc.ec.europa.eu/datasets_list.php?v=41), 2011.

EMEP (ftp://ftp.met.no/projects/emep/OpenSource2011/model_results_2008/), 2011.

Erisman, J. W. and Schaap, M.: The need for ammonia abatement with respect to secondary PM reductions in Europe, Environ. Pollut., 129, 159-163, 2004 
Fournier, N., Dore, A. J., Vieno, M., Weston, K. J., Dragosits, U., and Sutton, M. A.: Modeling the deposition of atmospheric oxidized nitrogen and sulphur to the UK using a multi-layer longrange transport model, Atmos. Environ., 38, 683-694, 2004.

Fowler, D., Flechard, C., Skiba, U., Coyle, M., and Cape, J. N.: The atmospheric budget of oxidized nitrogen and its role in ozone formation and deposition, New Phyto., 193, 11-23, 1998

GAINS (http://gains.iiasa.ac.at/gains/emissions.EAS/index.menu? pollutant), 2009.

He, C., Wang, X., Liu, X., Fangmeier, A., Christie, P., and Zhang, F.: Nitrogen deposition and its contribution to nutrient inputs to intensively managed agricultural ecosystems, Ecol. Appl., 20, 80-90, 2010.

He, K., Huo, H., and Zhang, Q.: Urban air pollution in China: current status, characteristics, and progress, Annu. Rev. Energy Environ., 27, 397-431, 2002.

Hertel, O., Skjøth, C. A., Frohn, L. M., Vignati, E., Frydendall, J., De Leeuw, G., Schwarz, U., and Reis, S.: Assessment of the atmospheric nitrogen and sulphur inputs into the North Sea using a Lagrangian model, Phys. Chem. Earth, 27, 1507-1515, 2002.

Holloway, T., Levy II, H., and Carmicheal, G.: Transfer of reactive nitrogen in Asia: development and evaluation of a sourcereceptor model, Atmos. Environ., 36, 4251-4264, 2002.

Jonson, J. E., Bartnicki, J., Olendrzynski, K., Jakobsen, H. A., and Berge, E.: EMEP Eulerian model for atmospheric transport and deposition of nitrogen species over Europe, Environ. Pollut., 102, 289-298, 1998.

Ju, X. T., Xing, G. X., Chen, X. P., Zhang, S. L., Zhang, L. J., Liu, X. J., Cui, Z. L., Yin, B., Christie, P., Zhu, Z. L., and Zhang, F. S.: Reducing environmental risk by improving $\mathrm{N}$ management in intensive Chinese agricultural system, Proc. Natl. Acad. Sci., 106, 3041-3046, 2009.

Kato, N. and Akimoto, H.: Anthropogenic emissions of $\mathrm{SO}_{2}$ and $\mathrm{NO}_{\mathrm{x}}$ in Asia: emission inventories, Atmos. Environ., 26A, 29973017, 1992.

Kim, J. and Cho, S. Y.: A numerical simulation of present and future acid deposition in North East Asia using a comprehensive acid deposition model, Atmos. Environ., 37, 3375-3383, 2003.

Kim, T. W., Lee, K., Najjar, R. G., Jeong, H. D., and Jeong, H. J.: Increasing $\mathrm{N}$ abundance in the Northwestern Pacific Ocean due to atmospheric nitrogen deposition, Science, doi:10.1126/science.1206583, 2011.

Kryza, M.: Application of a lagrangian model FRAME to estimate reduced nitrogen deposition and ammonia concentrations in Poland, in: Atmospheric Ammonia: detecting emission changes and environmental impacts, edited by: Sutton, M. A., Reis, S., Baker, S. M., Springer, 359-366, 2009.

Langner, J., Bergström, R., and Foltescu, V.: Impact of climate change on surface ozone and deposition of sulphur and nitrogen in Europe, Atmos. Environ., 39, 1129-1141, 2005.

Liu, X., Duan, L., Mo, J., Du, E., Shen, J., Lu, X., Zhang, Y., Zhou, X., He, C., and Zhang, F.: Nitrogen deposition and its ecological impact in China: an overview, Environ. Pollut., 159, 2251-2264, 2011.

Lü, C. and Tian, H.: Spatial and temporal patterns of nitrogen deposition in China: synthesis of observational data, J. Geophys. Res., 112, D22S05; doi:10.1029/2006JD007990, 2007.
Matson, P., Lohse, K. A., and Hall, S.: The globalization of nitrogen deposition: consequences for terrestrial ecosystems, Ambio, 31, 113-119, 2002.

Pan, Q. M., Bai, Y. F., Han, X. G., and Yang, J. C.: Effects of nitrogen additions on a leymus chinesensis population in a typical steppe of Inner Mongolia, Acta Phytotaxon. Sin., 29, 311-317, 2005.

REAS (http://www.jamstec.go.jp/frcgc/research/p3/emission.htm), 2006.

Reis, S., Pinder, R. W., Zhang, M., Lijie, G., and Sutton, M. A.: Reactive nitrogen in atmospheric emission inventories, Atmos. Chem. Phys., 9, 7657-7677, doi:10.5194/acp-9-7657-2009, 2009.

Richter, A., Burrows, J., Nü $\beta$, H., Granier, C., and Niemeier, U.: Increase in tropospheric nitrogen dioxide over China observed from space, Nature, 437, 129-132, 2005.

Shen, J. L., Tang, A. H., Liu, X. J., Fangmeier, A., Goulding, K. T. W., and Zhang, F. S.: High concentrations and dry deposition of reactive nitrogen species at two sites of the North China Plain, Environ. Pollut., 157, 3106-3113, 2009.

Shen, J. L., Tang, A. H., Liu, X. J., Kopsch, J., Fangmeier, A., Goulding, K., and Zhang, F. S.: Impacts of pollution controls on air quality in Beijing during the 2008 Olympic Games, J. Environ. Qual., 40, 37-45, 2011.

Simpson, D., Fagerli, H., Jonson, J.E., Tsyro, S., Wind, P., Touvinen, J.: Transboundary acidification, eutrophication and ground level ozone, in Europe. PART : unified EMEP model description. EMEP status report 2003, Norwegian Meteorological Institute, Oslo, 2003.

Singles, R. J., Sutton, M. A., and Weston, K. J.: A multi-layer model to describe the atmospheric transport and deposition of ammonia in Great Britain, Atmos. Environ., 32, 393-399, 1998.

Smith, R. I., Fowler, D., Sutton, M. A., Flechard, C., and Coyle, M.: Regional estimation of pollutant gas dry deposition in the UK: model description, sensitivity analyses and outputs, Atmos. Environ., 34, 3757-3777, 2000.

Streets, D. G. and Waldhoff, S. T.: Present and future emissions of air pollutants in China: $\mathrm{SO}_{2}, \mathrm{NO}_{\mathrm{x}}$, and $\mathrm{CO}$, Atmos. Environ., 34, 363-373, 2000.

Wang, S., Zhao, M., Xing, J., Wu, Y., Zhou, Y., Lei, Y., He, K., Fu, L., and Hao, J.: Quantifying the air pollutants emission reduction during the 2008 Olympic Games in Beijing, Environ. Sci. Technol., 44, 2490-2496, 2010.

Wang, X. P., Mauzerall, D. L., Hu, Y. T., Russell, A. G., Larson, E. D., Woo, J. H., Streets, D. G., and Guenther, Z.: A highresolution emission inventory for eastern China in 2000 and three scenarios for 2020, Atmos. Environ., 39, 5917-5933, 2005.

World Health Organization Air Quality Guidelines (http://www. who.int/topics/air_pollution/en/), 2005.

Zhang, Y., Dore, A. J., Ma, L., Liu, X. J., Ma, W. Q., Cape, J. N., and Zhang, F. S.: Agricultural ammonia emissions inventory and spatial distribution in the North China Plain, Environ. Pollut., 158, 490-501, 2010.

Zhang, Y., Liu, X. J., Fangmeier, A., Goulding, K. T. W., and Zhang, F. S.: Nitrogen inputs and isotopes in precipitation in the North China Plain, Atmos. Environ., 42, 1436-1448, 2008. 
Zhao, J. R., Guo, Q., Guo, J. R., Wei, D. M., Wang, C. W., Liu, Y., and Lin, K.: Investigation and analysis on current status of chemical fertilizer inputs and crop yields in agricultural field of Beijing Suburb, Journal of Beijing Agricultural Science, 15, 3638, 1997.
Zhao, Y. T., Li, X. F., Han, S. J., and Hu, Y. L.: Soil enzyme activities under two forest types as affected by different levels of nitrogen deposition, Chinese Journal of Applied Ecology, 19, 2769 2773, 2008. 